\title{
DEMAND - SUPPLY - TAXATION IN TIMES OF CRISIS
}

\author{
Delia Elena DIACONASU1, Ion POHOATA², Oana Ramona SOCOLIUC ${ }^{3}$
}

DOI: 10.1515/tjeb-2017-0006

The confrontation of the two doctrines, the Keynesianism and the Supply-side economics highlight that the Laffer perspective is the way to achieve solid economic growth on the long way and aims the core of an "exit from crisis" policy. Therefore, this article aims to analyze the hypothesis that a high level of taxation and public spending deters productive behavior and reduces economic growth during recessions. In other words, an easy taxation and low unproductive public spending are desirable for both, the enterprising investor and the consumer. Using the example of Romanian fiscal policy, on one side, we validated within a Vector Error Correction framework that an increase in government revenues harms consumption, investment and the level of employment, in conjunction with a procyclical behavior of fiscal authorities. On the other side, our results showed some positive effects of an increased government expenditures on consumption and employment, which can be explained by the accelerate deterioration of primary balance deficit and the Central Bank's low interest rate. Moreover, even though the initial positive response of investment to a government spending shock is positive, this is ephemeral and nonsignificant. Our findings highlight that, in order to reach growth on the long-run in times of crisis, the Romanian economy should adopt the fiscal policy and measures suggested by the Supply-side Economics.

Keywords: $\quad$ Fiscal policy, Consumption, Investment, Vector Error Correction, Crisis

\section{JEL Classification: E12, E62, B23}

\footnotetext{
${ }^{1}$ Researcher PhD, Department of Research, Faculty of Economics and Business Administration, Alexandru loan Cuza University of lasi, Romania.

2 Professor PhD, Department of Economics and International Relations, Faculty of Economics and Business Administration, Alexandru loan Cuza University of Iasi, Romania.

${ }^{3}$ Lecturer PhD, Department of Economics and International Relations, Faculty of Economics and Business Administration, Alexandru loan Cuza University of Iasi, Romania.
} 
Diaconasu, D.E., Pohoata, I., \& Socoliuc, O.R. (2017).

\section{Introduction}

We do not pretend that the confrontation of the two main doctrines which have guided the post-war economic thought and decisions, namely Keynesianism and the Supply side economics, illustrates a pioneering endeavor. But, we highlight some novel aspects regarding both theories on the basis of a comparative analysis and, mainly, by having a particular focus on the fiscal component. We achieve such aim by sending the analysis towards the intimate structures of the two doctrines. There we will find out that Keynesianism, considered a revolutionary scientific paradigm, has become in times of crisis a religion or a dogma. Keynesianism is about to reinforce the dangerous tradition of crises recurrence, a phenomenon that is presently aspiring to normality. We will demonstrate that despite its scientific and acknowledged status and the fact that the most part of the explanations about the crisis are following the Keynesian logic, such doctrine contains a large amount of populist opportunism. This ensured its success and not the rude attempt at the fundamental truths of Economics, among which the deliberate renunciation at the function of standard value of money is only one example. In counterpart, the Supply side economics, a doctrine faithful to science registers, did not enjoyed the same appreciation. The overlapping of the theoretical registers of the two main doctrines is useful and enlightening for the message both are sending at the normative level: that of natural evolution, without syncope, if we are following the way of Laffer, or that of taking the risk of crises recurrence, if we are following the path of Keynes. And, we repeat, the fiscal policy will take central stage in our endeavor. In the end of the paper we intend a validation of our theoretical assertions based on a case study referring to an emerging market, namely Romania, for the post-crisis period.

\section{Defining the Problem}

The theory of demand and supply has attended the history of economic thought in his entire evolutionary process. The classical lesson inserted the subject in the general framework of reproduction in which production, repartition, exchange and consumption appear as distinct but organically connected phases of a one-way process: to satisfy consumption needs through production, repartition and exchange. The representatives of the mainstream economics, through Alfred Marshall, preserved the Say-Ricardo path and approached these moments in their strong interdependence. What is communicating this elementary but rigorous lesson over time? First of all, it tells us that economic growth is the basic topic of Economics and that consumption always remain the finality of this process. Then, wealth is achieved only if all the three moments which precedes consumption are efficiently managed. Privileging a sequence and laying on the account that growth can be boosted by putting all other sequences in parenthesis appears theoretically a myth. Such a statute can be received by a

\section{DE GRUYTER OPEN}

Timisoara Journal of Economics and Business | ISSN: 2286-0991 | www.tjeb.ro Year 2017 | Volume 10 | Issue 1 | Pages: 88-103 
Diaconasu, D.E., Pohoata, I., \& Socoliuc, O.R. (2017).

Demand - supply - taxation in times of crisis

policy based either on supply or on demand. However, within both theory and practice, the above-mentioned moments were separated from the whole and separately analyzed; in theory from didactic reasons, in practice, from the need of some "necessary adjustments" subordinated to political goals.

The true breakage and dislocation of these two moments that converted them into distinct topics from a theoretical and practical perspective began with the Keynesian era. Since then it is believed that the "Say Law" is left behind and government can focus either on demand or on supply, but not on both simultaneously. A careful analysis highlights the fact that neither the classics nor the neoclassics have ever imagined that demand meets the supply physically, good by good, in the form of barter. An economist such as Paul Krugman, and he is not the only one, is able to believe and write that the classical model of Say "was, essentially, a model of a barter economy, in which money and nominal prices do not matter [...] It was a model in which Say's Law applied: supply automatically creates its own demand, because income must be spent" (Krugman, 2009a: 44-45). Besides the fact that the interpretation of the Say's Law is wrong (its profound meaning being that supply implicitly includes demand - a principle with applicability at the macroeconomic level), we state that no classical or neoclassical economist deserve such a detraction. Their theory about money and prices was not "appended in a nonessential way, like a veneer on a tabletop" (Krugman, 2009a: 44). On the contrary, the strongest argued lesson about money, their origin and functions was written, on the same logical structure, by a classical economist, with a special orientation, it is true, Karl Marx (1909) and a neoclassical economist, Carl Menger (2009). Compared with what they have left on this topic, the contribution of contemporary epigones goes to the "appendix" rubric. But money and prices were not the only "ingredients" (term belonging to Keynes) seen by the fathers of political economy as interposing between demand and supply. In the dynamics of the process that must balance the two terms of the equation they have noticed that there are several aspects which also matter, such as: the philosophy of profit, wages and employment, interest and credit, savings and investments, government spending and the State, taxes and social security, etc. In other words, they found that in order to cover consumption the correspondence between demand and supply is mediated by lever values and also by statist rules and organisms. They relied on the fact that free market with its inherent virtues of selfhealing ensures the correlation of all these factors' action in order to acquire equilibrium. What must be also remembered from the above-mentioned authors is that consumption is reached only through work, through production. Work provides the necessary income either to satisfy consumption needs or to materialize investments by accumulation through increasing savings. Their microeconomic approach comprises the following two major statements: a) in order to manufacture more capital goods through savings and investments, consumption must be restricted for a certain period of time; b) in order to consume, the individual must first acquire the necessary income through production. The last sentence will be ad-litteram used by Ludwig von Mises (1995). However, the idea is that accumulation is the source of development. The more capital goods we produce, reducing consumption in the

\section{DE GRUYTER OPEN}


Diaconasu, D.E., Pohoata, I., \& Socoliuc, O.R. (2017). of Economics and Business

Demand - supply - taxation in times of crisis

present, the more consumption goods we may produce in the future. This is also the path of economic progress.

But what happens if there are not enough savings to be converted into investments? Or what happens if we overreach and consume beyond the effective income? If we choose this way, obviously someone will stop us; and that someone is the crisis. The problem, worthy of an epistemological analysis, is that some economists argue, apparently credible, that an insufficiency of effective demand in its both components: consumption and investments, is leading to standstill. Conversely, others put the issues on the account of supply deficit caused by the alteration of the real savings mechanism. The first direction is associated with Keynes' name; Laffer provides the label for the second direction.

The confrontation of the two ways of thinking requires large spaces. Here we are interested only in that part which is consonant with the title of the article, namely the confrontation part which involves fiscal policy.

\section{The general confiscatory nature of taxation}

Taxation is connected with anything from the economy. Its connection with the crisis is easy to emphasize. Basically, any fiscal burden "shaves" the individual; it reduces the propensity towards saving from a diminished income and is affecting, consequently, the accumulation and investment. Why are we accepting this? For the same reasons for which we accept the State as a necessary evil designed to manage public matters at the macro level in order to make our life possible. But the problem is one of large scale: how much is normal to cede from our earnings - wages or profits - to the state in order to ensure the proper functioning of the citadel? We are used to believe that normality is placed somewhere between two extreme landmarks. On one hand, trying to "send" towards the State any income deriving from labor or capital would have, idealistically thinking, as correspondent the situation in which the State possesses the whole scene of the human action, as does the firm of Ronald Coase (Williamson \& Winter, 1997). It is hard to believe that such an idea can acquire concreteness. And yet, we do have a convenient example; the one of a Romanian economist belonging to both the academic environment and the managerial exercise at the macro level. We name Liviu Voinea who completely believes that "when nominal wages are increasing by $20-30 \%$ every year, is tragically if budgetary revenues from the income tax are not expanding at least with the same rate" (Voinea, 2009: 113).

On the other hand, the other landmark is taking shape under the light of the philosophy of the "enemy" State; of the endemic State, convict to inefficiency, reason why we have to send it to the area of the minimum necessary. A James Buchanan is more than probative for what is meaning the "invasive" and "robber" State with the incomes of those who have offered

\section{DE GRUYTER OPEN}

Timisoara Journal of Economics and Business | ISSN: 2286-0991 | www.tjeb.ro Year 2017 | Volume 10 | Issue 1 | Pages: 88-103 
Diaconasu, D.E.; Pohoata, I., \& Socoliuc, O.R. (2017).

Demand - supply - taxation in times of crisis

their vote (Buchanan \& Tollison, 1984). Theoretically, the econometrics, and not just this, can "scientifically" support what it should be an "optimum tax rate". Usually, we find this measure in times of crisis. The relationship between taxation and crisis is easy to reveal but only in strong connection with the monetary policy. Analyzed only from this perspective it reveals its "tyrannical nature" (Salin, 2014).

\section{The vitiation of the classical lesson. The Keynes moment - a success of circumstance}

It is said that the great breakage and change of paradigm materialized by Keynes occurred in relation with the "Say's Law". The author of the General Theory itself highlights this fact (Keynes, 2009). And he claims that the entire content of his book is intended to be an overthrow of the classical vision about the automatism of the economic life. With the specification that, in many perspectives, as an ex-liberal in good times, Keynes is confirming the classics and, inclusively, Say, we do believe that the breakage that we were talking about and that is never brought into the light regards money and their role. Furthermore, strongly related to this fact there is the vitiation of the nature of public expenditures and taxation.

Here is what is it about: Keynes flirts in a dilemmatic way with the functions of money and oscillates with the judgements between two landmarks. The first one is assessed by the function of money as a measure of value. It is a function which seems to confuse him. Consequently, he notes that "if by money we mean the standard of value, it is clear that it is not necessarily the money-rate of interest which makes the trouble" (Keynes, 2009: 295). But, he continues as if he was embarrassed by what he stated, "if money could be grown like a crop or manufactured like a motor-car, depressions would be avoided or mitigated (...)" (Keynes, 2009: 297).

The desire to get rid of the imposed aforementioned "standard of value" becomes the clearly stated temptation of a lax money emission discharged from the limits imposed by the gold standard. A temptation that finds its solution in the medium of exchange function of money. With the courageous hypothesis according to which their utility is "solely derived from its exchange-value", money is perceived by Keynes as a "bottomless sink for purchasing power, when the demand for it increases (...)" (Keynes, 2009: 297).

Throwing the classic lesson about money at the garbage can of history, Keynes is making "revolution" considering that the effective money supply does not have fixed landmarks; it has to be adapted to the needs of the economy. Briefly, what does this "revolution" means? It represents:

- An additional money emission until the credit becomes so cheap that is placed below the level of the profit rate, also struck and reduced by the crisis;

\section{DE GRUYTER OPEN}


Diaconasu, D.E., Pohoata, I., \& Socoliuc, O.R. (2017). of Economics and Business

Demand - supply - taxation in times of crisis

- High public expenditures, apparently, to compensate the lack of the private ones and to create new jobs;

- High taxation to ensure the existence of a budding monster, the Keynesian state, and to provide a source for the public spending.

For the "scientific" Keynes it did not matter that:

- The additional amount of money placed into the circulation channels had no real correspondent in an increasingly fragile economy, being thus the unhealthy source of the inflationary growth;

- The additional amount of money obtained based on a higher level of taxation oriented towards public expenditures illustrated a disadvantage for the private expenditures of entrepreneurs and consumers which were affected, on this way, in terms of income contraction. It was not convenient to see that the State does not make public spending from its own money;

- The work places offered by the State without any real support and aggressively created, correspond to the lack of jobs from the private sector, deprived of the opportunity to generate them due to a confiscatory taxation.

What legacy leaves such a theoretical construction brightened by the aura of a circumstance success? A harmful one, we might say, from at least two perspectives. First, it aggressively and apologetically disavows great truths of Economics, humiliating and considering it as having a relative importance. Second, through its adhesion guaranteed by its inherent populism will ensure the recurrence of great depressions, throwing into derisory any serious lesson about crisis. It is totally impossible to provide a lesson that will present the crisis as a simple accident and not a permanent component of the economic dynamics by following the "logic" of the Keynesian therapeutics. And if such a lesson is also validated by famous Nobel laureates in Economics like Stiglitz (2010; 2013; 2015), Krugman (2009a; 2009b; 2012) or Roubini (2010), then the lastingness of the marriage with the crisis is ensured. From the multitude of adverse effects mentioned above, several places worth reflection, such as:

- The establishment of false targets. Keynesianism is transforming employment in the main goal of any economic policy which intends to be successful. The favorable interpretations of the "General Theory" bring apparently credible arguments to such a goal. However, the full employment - a desirable essential component of economic and social peace, is a result and not a starting point (Salin, 2014). What kind of entrepreneur starts his business focusing firstly on the employment part? Profit is his motivation; and, if with this occasion new jobs are created, is even better. The State is the only "entrepreneur", investor of last resort that can afford the luxury of thinking like this. And he does so because he is not threatened by the institution of bankruptcy on the basis of a strict accounting calculation of revenues and expenses. Afterwards, another deceptive target regards the budgetary optimum. Keynesian philosophy is inducing the idea of a budgetary optimum definable by maximum budget

DE GRUYTER OPEN 
Diaconasu, D.E., Pohoata, I., \& Socoliuc, O.R. (2017).

Demand - supply - taxation in times of crisis

revenues. From here "the rationale" of a high taxation. But, if the optimum was the individual well-being of every citizen, the Keynesian theory would become obsolete.

- Encouraging the "propensity towards savings" in the circumstances of a high taxation. This is a logical inadequacy of large proportions. Savings do not need to be encouraged. It has to be left to follow its natural course, as it followed it throughout history, with or without Keynes. But how to encourage savings if suppressing its source through a suffocating taxation?

- Living from "dissavings" by lending and investing from non-voluntary savings, using the tool of public debt, translatable into high taxation, proves to be a perverse choice, a self-cancelling of the fragile and temporary successes. When such a hypothesis becomes acceptable and part of the working agenda of some international organisms, such as IMF or the World Bank, the risk to follow an unstable path on long-run is even higher.

- The encouragement of consumption (a component of the effective demand), when the crisis is generated by a deficit of savings produced on the basis of a discouraging taxation, is equivalent with an even higher contraction of savings. Even though such proposition is lacking logic, it captures the attention because is the most populist.

- The occurrence of two anti-economic and anti-free market "monsters", a synthesis of the Keynesian evil: the State, as investor of last resort and the Central Bank, as lender of last resort. The first one merges individual savings through taxes in order to spend them publicly, following criteria placed outside the economic lessons. The second one mingles and nationalizes the credit and operates with money without being constrained by any standard of value and without being responsible in front of anyone. The permanent "marriage", but especially their concerted intervention in times of crisis through the channels of monetary and fiscal policies provides the necessary basis for crisis recurrence in historical perspective.

\section{Laffer moment. Normal economic targets on the basis of lower taxation}

It is well known that the Laffer moment is referring to the Supply-side doctrine, a liberal one which is placed, from the perspective of ideas that it shares, in the extent of the English and French classical School, as well as of the Austrian School of Economics. Furthermore, it also shows a large interference area with the hard-core ideas of Friedman's monetarism. Having such origins and adjacency its occurrence as a response to the Keynesian philosophy is logical. From the perspective of our research topic, the structure of such reaction is referring to several nodal aspects:

- The equivalent value for money is remaining a landmark of monetary and fiscal policies; as such, investments should be made from voluntary savings, while artificially created liquidity with the consent of the Central Bank would appear as deceitful. The magic wand of budgetary deficit and the game with money created from nothing become excrescences of some economic policies which have nothing to do with the economic science. The main activity object of the false investors or lenders of last resort disappears.

\section{DE GRUYTER OPEN}

Timisoara Journal of Economics and Business | ISSN: 2286-0991 | www.tjeb.ro Year 2017 | Volume 10 | Issue 1 | Pages: 88-103 
Diaconasu, D.E., Pohoata, I., \& Socoliuc, O.R. (2017).

Demand - supply - taxation in times of crisis

- Oppressive taxation is discouraging all the actors of the economic life, but mainly the entrepreneurs. And they must be encouraged, giving the fact that they are strictly connected to production, supply, in other words, to the origins from where all the other things are coming from (Canto, Jones, \& Laffer, 1982). In the same time, a higher taxation level is negatively affecting both demand and supply. It also generates repercussions on the free market mechanism regarding resources allocation following its own levers - the price and the incentive system. Conclusively, high taxation diminishes the amplitude of economic growth, and a reduced wealth cannot be compensated through fiscal redistribution.

- Public expenditures illustrate nothing more than the "negative" of what is abusively and confiscatory taken by the State from the individual incomes of the people in order to be spent in an inefficient, unsustainable and populist manner. They are not adding, but replacing the expenditures from the private area.

- The false targets of the economic policy are disappearing. In the spirit of the classical economic theory and by a declared return to the Say's Law, it is believed, on a reasonable ground, that "the demand is implicit in the supply" (Gilder, 1981: 25). Those who are wealth creators do this by paying salaries to those people who participate at this process; and from the obtained revenues people can consume, save, invest, etc. Within such a mechanism jobs creation is an implicit logical aspect. As a bridge over time, Say is on the same wavelength with Laffer and Mises, considering that logically, the one who hires must pay the one who works. Otherwise, its business would not even exist, as well as the demand for its products or the ones of other entrepreneurs.

At the same time, the microeconomic approach is transforming the affinity towards budgetary revenues maximization by all means, as a budgetary optimum, into an obsolete matter. The revenues can be large or small. Important is to increase, on their basis, the living standards of citizens. To such an objective must be subordinated inclusively the calculation of determining an optimal rate of taxation. And, noteworthy, it is counting on the contraction of the taxation rate with positive effects not only on savings and investments, but also on labor - through the increase of the price of free time, and on tax evasion, which is not so "charming" for lower rates of taxation. With a remarkable synthesis force, Norman Ture generously surprises the opposed structure of the doctrine that he reflects in the following terms: "By definition, aggregate demand is the sum of purchases of all types by all economic entities governments, businesses, households, etc. Also by definition, these outlays must exactly equal aggregate income which in turn, at every moment in time, must just equal the value of aggregate output. Changes in real income, therefore, occur only as changes in output occur. And changes in output occur only as a result of changes in the amount of production inputs or in the intensity or efficiency of their use. To have a first-order effect on income, therefore, government actions would have to alter directly the amount or effectiveness of production inputs committed to production. But government actions, in and of themselves, do not change the aggregate amount of production resources available in the economy or their productivity. Changes in the amount of production inputs committed to production will result only if the real rewards for their use, i.e., the real price received per unit of input, is changed." (Ture,

\section{DE GRUYTER OPEN}

Timisoara Journal of Economics and Business | ISSN: 2286-0991 | www.tjeb.ro Year 2017 | Volume 10 | Issue 1 | Pages: 88-103 
Diaconasu, D.E., Pohoata, I., \& Socoliuc, O.R. (2017).

Demand - supply - taxation in times of crisis

1982: 13). In concise terms, the author provides clarifying arguments in order to convince that global demand is nothing more than a reflex of production, one that is true, is mediated by prices.

As the Keynesianism "multiplied itself" in a large number of adepts rather political than scientifically interested, also Laffer, Gilder or Ture did not pass throughout Economics without leaving a legacy. And we can discuss about a deep legacy if we take into consideration the prominent interest of those who are representing today the Austrian School of Economics and the registers on which they are consuming their thoughts. A Huerta de Soto (2009) or Hülsmann (2008) offer, in our point of view, representativeness for the path initiated by Menger, Mises or Hayek.

\section{A case study on the effects of the fiscal policy on economic growth of Romania in times of crisis}

Starting with 2008, the global economic crisis has begun to be deeply felt in Romania. As a direct consequence, radical fiscal adjustment actions have arisen, and they were not few. Briefly, the so-called fiscal consolidation measures designed to provide the foundations of stability meant increasing indirect taxation and modifications regarding direct taxation and social contributions.

In this study we try to find if the Keynesian fiscal measures were able to promote, support and accomplish the economic growth and stability in Romania, in the aftermath of the crisis. And we do this by developing a Vector Error Correction Model (VECM) having as endogenous variables the following: government expenditures (Gov_exp), net government revenues (Gov_rev), gross fixed capital formation (GFCF), final consumption, 3-months interest rate (IRS_3m) and unemployment rate. Following Blanchard and Perotti (2002) and Mountford and Uhlig (2009), public spending and revenue are not including current and capital transfers and interest payments on government debt.

The source of the quarterly data is Eurostat database and the timespan ranges between 2008Q1 and 2016Q4. All series, except the interest rate and unemployment rate are expressed in national currency units, seasonally adjusted using Tramo-Seats algorithm, expressed in real terms, using the GDP deflator and taken in natural logarithms.

Before estimating the model, stationary tests were employed. The results of the Augmented Dickey-Fuller, Phillips-Perron and Kwiatkowski-Phillips-Schmidt-Shin Unit Root Tests revealed that government expenditures and revenues are stationary in levels, while gross fixed capital formation, final consumption, short-term interest rate and unemployment rate are stationary in the first difference. Having I(1) variables, we proceeded with the Johansen

\section{DE GRUYTER OPEN}


Diaconasu, D.E., Pohoata, I., \& Socoliuc, O.R. (2017).

Demand - supply - taxation in times of crisis

and Juselius procedure in order to find the long-term relationships between them. In line with Lutkepohl (2004), we perform cointegration tests on all pairs of series before turning to the six-dimensional system. The results of the Johansen trace and maximum eigenvalue tests showed 4 cointegrating vectors at the 0.05 level. Therefore, having these cointegration features of the analyzed data, a Vector Error Correction Model is desirable within our paper.

\subsection{Methodology}

Based on the results of our cointegration analysis, in order to emphasize how an increase in public expenditures and revenues affect the economic development, we use the VEC methodology with the following general form:

$$
\Delta y_{t}=\Pi y_{t-1}+\Gamma_{1} \Delta y_{t-1}+\cdots+\Gamma_{p-1} \Delta y_{t-p+1}+u_{t}
$$

where $y_{t}$ is a $(K \times 1)$ vector of endogenous variables, $\Pi=\alpha \beta^{\prime}, \alpha$ and $\beta$ are $(K \times r)$ matrices with $\mathrm{rk}(\alpha)=\mathrm{rk}(\beta)=\mathrm{r}=4, \Gamma_{j}(j=1, \ldots, p-1)$ are $(K \times K)$ parameter matrices, $u_{t} \sim\left(0, \Sigma_{u}\right)$ is an unobservable error term, i.e. a standard white noise. $K$ is the number of time series variables and $r$ is the cointegration rank.

The vector of endogenous variables, $y_{t}$ is represented with the following form and order of the variables:

$$
\boldsymbol{y}_{\boldsymbol{t}}=\left[\begin{array}{c}
\text { Gov_exp } \\
\text { Gov_rev } \\
\text { Consumption } \\
\text { GFCF } \\
\text { IRS_3m } \\
\text { Unemployment }
\end{array}\right]
$$

Applying the Cholesky decomposition of the variance-covariance matrix means that the recursive structure plays a central role in defining the model. Firstly, following Blanchard and Perotti (2002) we assume that expenditure decisions are prior to tax ones. Then, following Auerbach and Gorodnichenko (2012) and Puonti (2016) we use the above-mentioned ordering in our baseline specification: government variables, GDP components, monetary policy, unemployment rate.

Regarding the deterministic terms, a linear time trend is included properly because, except of unemployment, all the time series exhibit a trending behavior. The number of lags is chosen by asking the model selection criteria based on the levels the unrestricted VAR model specified for a maximum lag order of 4, taking into consideration the data frequency. In order to check if the fitted VECM provides a good representation of the time series set, we test

\section{DE GRUYTER OPEN}


Diaconasu, D.E., Pohoata, I., \& Socoliuc, O.R. (2017).

Demand - supply - taxation in times of crisis

against the residual autocorrelation, LM test, non-normality, ARCH effects and parameter instability. The residual diagnosis tests provided the following results: residual autocorrelation, no serial correlation, residuals are multivariate normal, no ARCH effects. The CUSUM test and recursive coefficients showed that parameters are stable. Next, the fitted VECM model with 2 lags and 4 cointegration vectors, $\operatorname{VECM~}(2,4)$ is used to identify the fiscal policy shocks.

\subsection{Empirical results}

Figure 1 plots the responses of the endogenous variables to a positive government expenditure shock in Romania, after the big degringolade. For each variable, the model-based response lies within the 95 percent confidence interval (Efron and Hall Percentiles) estimated with bootstrap method of 300 replications.

Gov_exp $\rightarrow$ Gov_exp

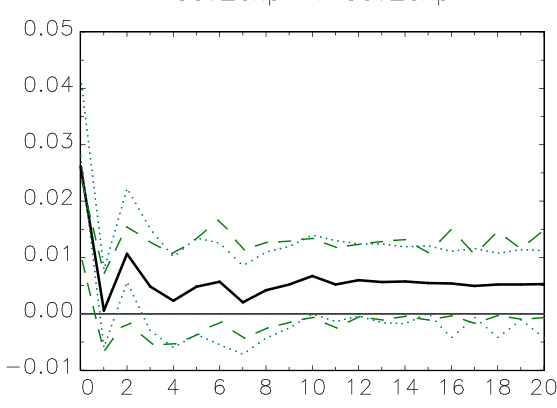

Gov_exp $\rightarrow$ GFCF

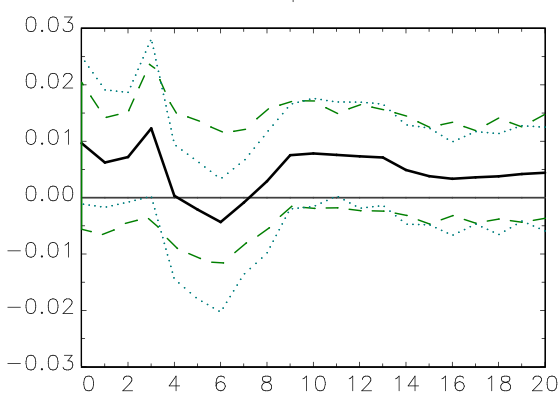

Gov exp $\rightarrow$ Gov rev

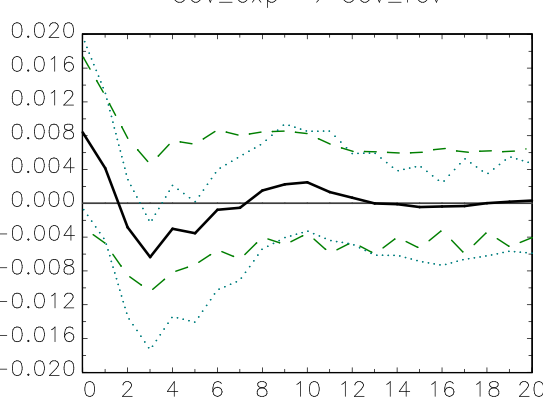

Gov_exp $\rightarrow$ IRS_3m

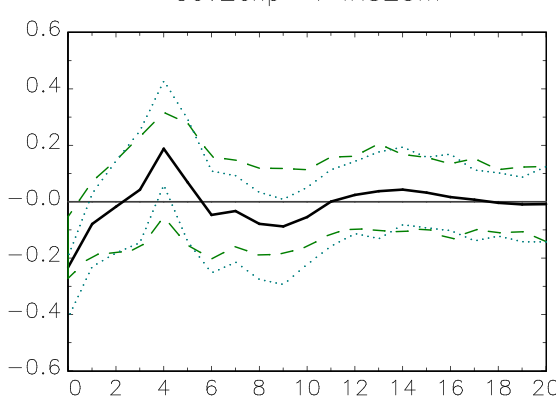

Gov_exp $\rightarrow$ Consumption

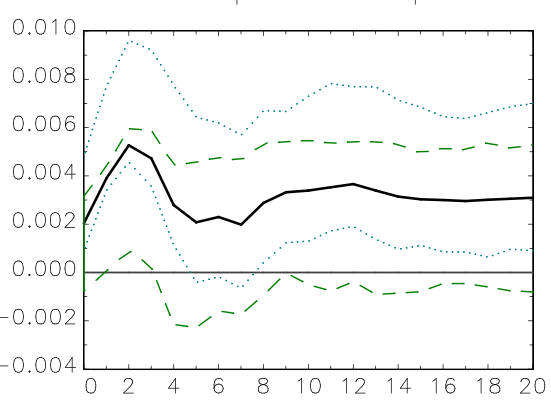

Gov_exp $->$ Unemployment

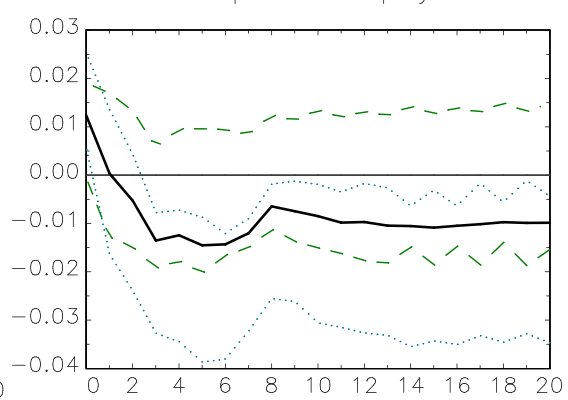

Figure 1. Impulses generated from a government expenditure shock

Source: own estimates

Notes: VECM Orthogonal Responses (solid line) of Government expenditure, Government revenue, Consumption, Gross Fixed Capital Formation, 3-months Interest rate and Unemployment rate to a shock in Government expenditure together with 95\% Efron boostrap confidence interval (dashed line) and 95\% Hall boostrap confidence interval (dotted line) based on 300 replications; Vertical axis - deviation from the baseline scenario, horizontal axis - number of months after the shock.

\section{DE GRUYTER} OPEN
Timisoara Journal of Economics and Business | ISSN: 2286-0991 | www.tjeb.ro

Year 2017 | Volume 10 | Issue 1 | Pages: 88-103 
Diaconasu, D.E., Pohoata, I., \& Socoliuc, O.R. (2017). of Economics and Business

Demand - supply - taxation in times of crisis

The interpretation of the graphs is not easy since the time horizon that we considered does not have a linear evolution of economic dynamics and policy in Romania, in the sense that from 2008 it has been affected by the actual crisis and the analyzed period includes four presidential and legislative election campaigns. However, what are communicating these graphs?

The main idea is that the analyzed period has not provided a liberal environment in which the Laffer curve could have the desired effect, but rather it was believed in the efficacy of public spending and the "generosity" of the fiscal state. Briefly, Figure 1 shows:

- The first graph displays the response of the government expenditure to its own shock. The little persistence of public expenditure impulse is on the same wavelength with the existing literature (Giordano, Momigliano, Neri, \& Perotti, 2007).

- The second graph shows that an increase of $1 \%$ in the government expenditure determines a decrease of government revenues, still nonsignificant. This situation is as we expected. In Romania, the high level of taxation was achieved mainly through taxes on good and services which are the main pillars of the tax revenues (Daianu, Kállai, \& Lungu, 2012). But, a higher level of taxation encourages the economic activity on the black market, the number of tax payers falls, and therefore the tax revenues decrease. And, moreover, according to the World Bank report of 2011, Romania was ranked next to the last 183 states, according to the number of corporate tax delinquencies. In these circumstances, the high and economically unproductive public spending could not be covered only through high taxes, but also through foreign debt (Zaman, 2011).

- The third graph illustrates the impact of government spending on final consumption. The increase of government expenditure raises consumption, which peaks in the 2nd quarter after the shock. This upward and statistically significant trend can be explained through the demand multiplier effect of public expenditure (de Castro \& de Cos, 2008). Also, the idea that the source of income is not represented by the voluntary savings, but the borrowed ones, is plausible.

- The fourth graph displays the response of investment to a shock in the government expenditure. As can be seen, the figure shapes an oscillatory movement which is not statistically significant. However, the trend is downward. The initial positive effect of increasing government spending, opposed to what we have expected, might have been antagonized by the low interest rate.

- The fifth graph illustrates the reaction of interest rate to an increase in government spending. The short-lived negative relation between these two variables may be related to the procyclical behavior of fiscal policy in Romania, during downturns. Also, Petrevski, Bogoev and Tevdovski (2016) state that in the case of Macedonia, monetary and fiscal policies act as strategic substitutes.

DE GRUYTER OPEN
Timisoara Journal of Economics and Business | ISSN: 2286-0991 | www.tjeb.ro Year 2017 | Volume 10 | Issue 1 | Pages: 88-103 
Diaconasu, D.E., Pohoata, I., \& Socoliuc, O.R. (2017).

Demand - supply - taxation in times of crisis

- The last graph indicates that an increase of government expenditure determines a drop in the unemployment rate. This downtrend can be explained through "false" jobs created by the state in the unproductive sphere of services.
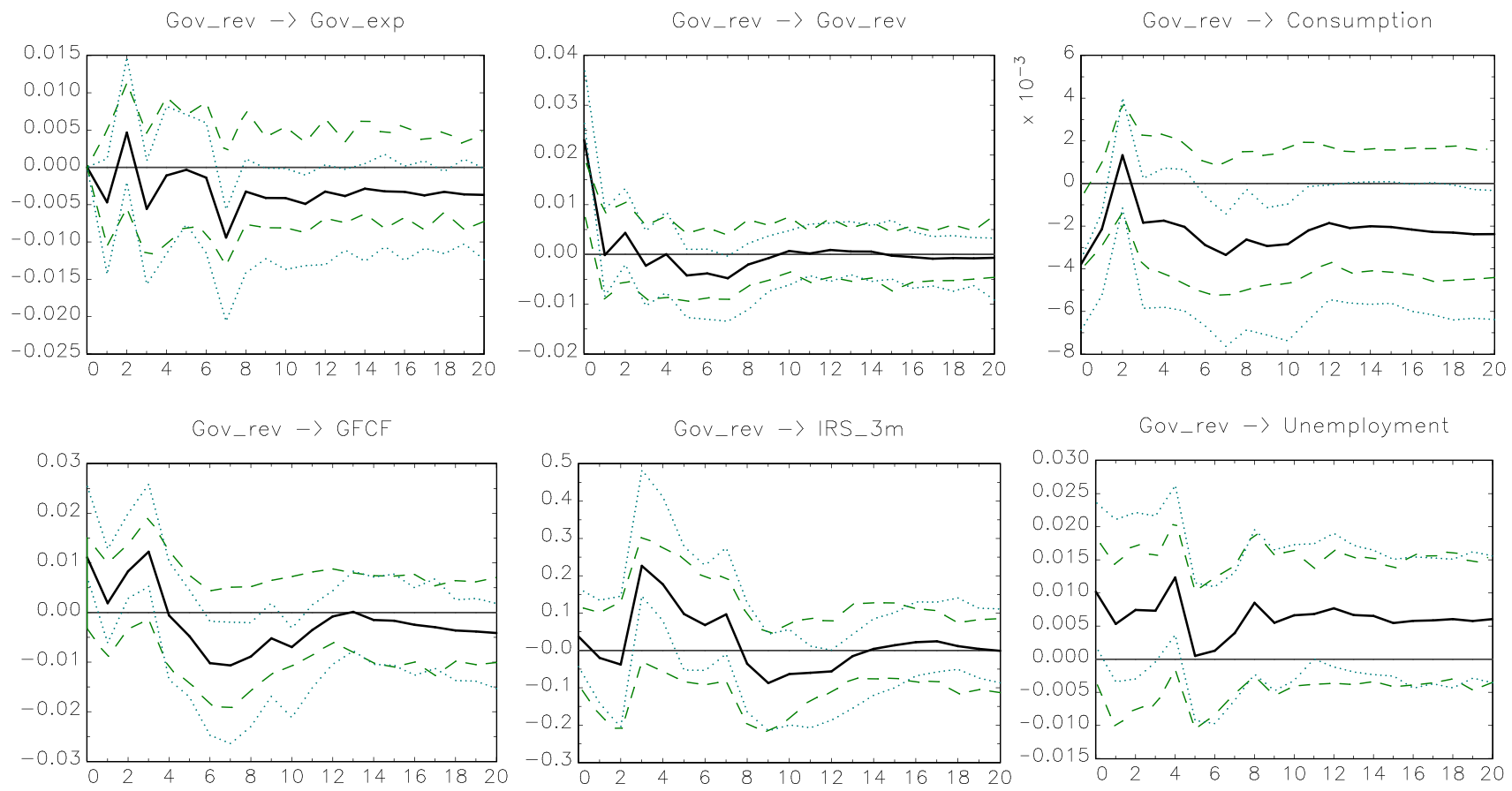

Figure 2. Impulses generated from a government revenue shock

Source: own estimates

Notes: VECM Orthogonal Responses (solid line) of Government expenditure, Government revenue, Consumption, Gross Fixed Capital Formation, 3-months Interest rate and Unemployment rate to a shock in Government revenue together with 95\% Efron boostrap confidence interval (dashed line) and 95\% Hall boostrap confidence interval (dotted line) based on 300 replications; Vertical axis - deviation from the baseline scenario, horizontal axis - number of months after the shock.

Briefly, Figure 2 shows:

- The same low persistency of public revenues, as in the above case;

- A drop in consumption as a response to an in increased taxation. This can be due to a decreasing in public expenditure during the crisis, in conjunction to a diminished income by taxes;

- A negative response of final consumption to a shock in public revenue, which is statistically significant in the first quarter. This is an expected result, given the increased VAT in the period July 2010-January 2017 corroborated with the decreased wages in the public sector;

\section{DE GRUYTER} OPEN
Timisoara Journal of Economics and Business | ISSN: 2286-0991 | www.tjeb.ro

Year 2017 | Volume 10 | Issue 1 | Pages: 88-103 
Diaconasu, D.E., Pohoata, I., \& Socoliuc, O.R. (2017).

Demand - supply - taxation in times of crisis

- An initial upraising trend of gross capital formation as a reaction to an increase in the level of taxation which can be due to the decreased interest rate that "thaws" the income. However, the effect becomes negative after the $4^{\text {th }}$ quarter;

- The response of interest rate follows the same pattern like in the above case;

- The increasing of unemployment rate. The fact that the main channel through which taxes affect economic growth is investment, and as a direct consequence, the level of employment, is a wide-known theory (Widmalm, 2001).

\section{Conclusions}

Why Keynes' "play" with money is still present? Because everything that comes on the path of Adam Smith, through Laffer and the Austrian School of Economics is following the path of the fundamental rules of economics. Keynesianism is an exception, is not following the same tradition. Even though its effects are counterproductive and risky on long-term, the measures that it proposes are compatible with political demagogy. The patronage network maintained by Keynesian public money illustrates a reason of undisguised appreciation of this theory (Braun \& Rallo, 2011). And what legacy leaves such a doctrine? Once more we are referring at:

- Serious reversal of some well-known causal relations: instead of adopting measures to stimulate the increase of wealth and recovery from crisis, with the increase of employment as a normal consequence, there are jobs created first which subsequently prove to be unsustainable;

- The sentencing of market, eternally labelled as imperfect, and often as fundamentalist and blamed for the appearance of crises, while the exacerbated and inadequate interventionism explains the great syncope;

- The achievement and assimilation of some permanent reflexes coming from the left-wingdoctrine with "chances" to be seen as innate in offering support precisely to those who should be punished through bankruptcy;

- The logical increase of the degree of social assistance at the same time with the increase of taxation which also acquires the innate status because it should serve the "state rationalities";

- Public indebtedness is losing any negative connotation. The budgetary equilibrium is becoming, as the gold currency, a "barbarian vestige", apparently not on the same wavelength with the price lending requirements of a modern economy. Moreover, the idea of public spending through its association with a carrying and responsible State is seriously but perversely making part from the implementation engineering of democracy depicted so well by James Buchanan (Buchanan \& Tollison, 1984);

- State intervention especially by the means of a random taxation in cohabitation with the Central Bank is converting the moral hazard into a constant of economic life;

DE GRUYTER OPEN 
Diaconasu, D.E., Pohoata, I., \& Socoliuc, O.R. (2017).

Demand - supply - taxation in times of crisis

- The size of the tax rate is lacking the rational Misesian calculus. It rather becomes support for a "fiscal State" that designs its policy and, consequently, the society, after its own purposes.

The empirical analysis applied on the case of fiscal policy in Romania confirms, in a more synthetic manner, what we aforementioned. Keynes emerges victorious, not on the scientific registers, but on the ones of the opportunistic populism, guiled placed within its theoretical structures and "scientifically" exploited by his today's epigones.

\section{References}

Auerbach, A.J., \& Gorodnichenko, Y. (2012). Measuring Output Responses to Fiscal Policy. American Economic Journal: Economic Policy, 4(2), 1-27. doi: 10.1257/pol.4.2.1

Blanchard, O., \& Perotti, R. (2002). An Empirical Characterization of the Dynamic Effects of Changes in Government Spending and Taxes on Output. The Quarterly Journal of Economics, 117(4), 1329-1368. doi: 10.1162/003355302320935043

Braun, R.C., \& Rallo, J.R. (2011). One Crisis and Five Errors. Iasi: University Alexandru Ioan Cuza Publishing.

Buchanan, J.M., \& Tollison, R.D. (1984). The Theory of Public Choice. Michigan: Michigan University Press.

Canto, V.A., Jones, D.H., \& Laffer, A.B. (1982). Foundations of Supply - Side Economics - Theory and Evidence. New York: Academic Press.

Daianu, D., Kállai, E., \& Lungu, L. (2012). Tax Policy Under the Curse of Low Revenues: The Case of Romania (Part I). Romanian Journal of Economic Forecasting, 15(1), 156-186.

De Castro, F., \& De Cos, H.P. (2008). The Economic Effects of Fiscal Policy: The Case of Spain. Journal of Macroeconomics, 30(3), 1005-1028. doi: 10.1016/j.jmacro.2007.08.009

de Soto, J.H. (2009). Money, Bank Credit and Economic Cycles. Auburn: Ludwig von Mises Institute.

Gilder, G. (1981). Moral sources of capitalism. Society, 18(6), 24-27. doi: 10.1007/BF03180594

Giordano, R., Momigliano, S., Neri, S., \& Perotti, R. (2007). The effects of fiscal policy in Italy: Evidence from a VAR model. European Journal of Political Economy, 23(3), 707-733. doi: 10.1016/j.ejpoleco.2006.10.005

Hülsmann, J.G. (2008). Deflation and Liberty. Auburn: Ludwig von Mises Institute.

Keynes, J.M. (2009). The General Theory of Employment, Interest and Money. Bucharest: Publica Publishing.

Krugman, P. (2009a). Introduction to the new edition of John Maynard Keynes's book The General Theory of Employment, Interest and Money. Bucharest: Publica Publishing House.

Krugman, P. (2009b). The Return of Depression Economics and the Crisis of 2008. Bucharest: Publica Publishing House.

Krugman, P. (2012). End This Depression Now. New York: W.W. Norton \& Company.

Lutkepohl, H. (2004). Applied Time Series Econometrics. Cambridge: Cambridge University Press.

DE GRUYTER OPEN 
Diaconasu, D.E., Pohoata, I., \& Socoliuc, O.R. (2017).

Demand - supply - taxation in times of crisis

Marx, K. (1909). Capital. A Critique of Political Economy, Volume I: The Process of Capitalist Production. Chicago: Charles H. Kerr and Company.

Menger, C. (2009). On the Origins of Money. Auburn: Ludwig von Mises Institute.

Mises, L. (1995). Economic Policy: Thoughts for Today and Tomorrow. Irvington: Free Market Books.

Mountford, A., \& Uhlig, H. (2009). What are the Effects of Fiscal Policy Shocks? Journal of Applied Econometrics, 24(6), 960-992. doi:10.1002/jae.1079

Petrevski, G., Bogoev, J., \& Tevdovski, D. (2016). Fiscal and Monetary Policy Effects in Three South Eastern European Economies. Empirical Economics, 50(2), 415-441. doi: /10.1007/s00181-015-0932-0

Puonti, P. (2016). Fiscal multipliers in a structural VEC model with mixed normal errors. Journal of Macroeconomics, 48(SP), 144-154. doi: 10.1016/j.jmacro.2016.03.003

Roubini, N., \& Mihm, S. (2010). Crisis Economics: A Crash Course in the Future of Finance. Bucharest: Publica Publishing.

Salin, P. (2014). Tax Tyranny. Paris: Odile Jacob Economie.

Stiglitz, J. (2010). Freefall: America, Free Markets, and the Sinking of the World Economy. Bucharest: Publica Publishing.

Stiglitz, J. (2013). The Price of Inequality. New York: Penguin Books Limited.

Stiglitz, J. (2015). The Great Divide. New York: Penguin Books Limited.

Ture, N.B. (1982). Supply Side Analysis and Public Policy. In D.G. Raboy (Ed.), Essays in Supply Side Economics (pp. 8-28). Washington, DC: Institute for Research on the Economics of Taxation.

Voinea, L. (2009). The end of the illusion economy. Bucharest: Publica Publishing.

Widmalm, F. (2001). Tax Structure and Growth: Are Some Taxes Better Than Others? Public Choice, 107(3/4), 199-219. doi: 10.1023/A:1010340017288

Williamson, O., \& Winter, S.G. (eds). (1997). The Nature of the Firm. Origins, Evolution and Development. Timisoara: Sedona Publishing.

Zaman, C. (2011). Assessing the Sustainability of Public Finances in Romania. Romanian Journal of Economic Forecasting, 14(2), 106-115. 